\title{
IMPLEMENTASI KOMPUTER GRAFIS PADA PERANCANGAN MOTIF BATIK PAPUA
}

\author{
Puri Sulistiyawati', Dimas Irawan Ihya' Ulumuddin ${ }^{2}$, Alif Putra Azhari ${ }^{3}$ \\ 1,2,3 Program Studi Desain Komunikasi Visual, Fakultas Ilmu Komputer \\ Universitas Dian Nuswantoro \\ 1 puri.sulistiya@gmail.com, \\ 2dimas.irawan@dsn.dinus.ac.id, \\ ${ }^{3}$ alifputraazhari97@gmail.com
}

\begin{abstract}
Abstrak
Batik Papua mempunyai potensi sebagai industri kreatif yang dapat mendukung sektor pariwisata daerah. Hadirnya batik papua dapat menjadi alternative souvenir yang menarik bagi wisatawan. Agar dapat memberikan variasi motif kepada wisatawan dalam memilih dan mengkoleksi motif batik papua perlu adanya inovasi dalam pengembangan motif batik. Melihat perkembangan batik modern saat ini, batik papua harus dapat berkembang sejalan dengan kemajuan teknologi agar dapat meningkatkan industri batik di papua. oleh sebab itu penelitian ini bertujuan untuk mengembangkan motif batik batik berbasis digital dengan komputer grafis. Metode yang digunakan dalam proses digitalisasi motif batik adalah dengan pendekatan penciptaan seni yang terdiri dari tahap eksplorasi, perancangan, dan perwujudan karya. Melalui pemanfaatan teknologi digital berbasis komputer grafis dalam pengembangan motif batik papua ini diharapkan dapat menjadi inovasi desain dan efisiensi dalam mengeksplorasi keunggulan, keunikan serta gagasan untuk pengembangan motif batik dan dapat meningkatkan industri batik papua.
\end{abstract}

Kata kunci: Batik Papua; Digitalisasi motif batik; Komputer Grafis

\begin{abstract}
:
Batik Papua has the potential as a creative industry that can support the regional tourism sector. The presence of Batik Papua can be an attractive alternative souvenir for tourists. To provide a variety of motifs for tourists in selecting and collecting Batik Papua motifs, there needs to be innovation in developing batik motifs. Seeing the development of modern batik today, Batik Papua must be able to develop in line with technological advancements to improve the batik industry in Papua. Therefore this research aims to develop digital batik motifs based on computer graphics. The method used in the process of digitizing batik motifs is the art creation approach consisting of the exploration, design, and embodiment stages of the work. Through the use of digital technology based on computer graphics in the development of Batik Papua motifs, it is hoped that it can be an innovation in design and efficiency in exploring excellence, uniqueness, and ideas for developing batik motifs and to improve the Batik Papua industry.
\end{abstract}

Keywords: Papuan Batik, Digitizing batik motifs, Computer Graphics

\section{PENDAHULUAN}

Indonesia merupakan Negara kepulauan yang kaya akan keindahan alam dan keragaman budaya. Salah satu keragaman budaya tersebut adalah batik. Keragaman motif batik yang tersebar diseluruh daerah memiliki karakteristik yang berbeda-beda disetiap daerah mengiikuti keadaan alam disetiap wilayah Indonesia dan perkembangan kebudayaan. Perbedaan tersebut terlihat pada warna dan motif pada kain batik. Namun, 
secara umum batik di Indonesia memiliki makna dan fungsi yang sama diseluruh wilayah. Yang mana melalui bahasa visual yang tergoreskan menggambarkan ungkapan atau makna filosofis yang mendalam. Meskipun batik selalu dikenal identik dengan jawa namun penyebaran batik ada diseluruh wilayah Indonesia, salah satunya papua.

Batik papua memiliki motif yang unik dan tidak kalah dengan batik didaerah lain. Motif pada batik papua yang berkembang dibeberapa wilayah adat papua melambangkan budaya dan alam dari setiap suku-suku yang ada di Papua. Ciri khas yang menonjol dari batik Papua adalah dari bentuk motif yang asimetris dan warna motif yang cenderung gelap dengan latar belakang cerah (Marthen \& Mambraku, 2014). Motif yang berkembang di papua terinspirasi dari keadaan alam, tradisi dan kebudayaan papua. Beberapa diantarnya adalah motif burung cendrawasih, patung asmat, tifa, busur-panah, rumah adat honai dan kapak batu. Dengan ciri khasnya yang identik dengan peninggalan-peninggalan arkeologi tentunya menjadikan daya tarik wisatawan terhadap batik Papua. Namun perkembangan batik Papua tidak seperti batik Jawa yang mampu dikenal hingga mancanegara. Hal ini disebabkan kurangnya inovasi dalam pembuatan motif batik dan terbatasnya sumber daya manusia (Salsabila, 2019). Melihat permasalahan tersebut perlu adanya inovasi untuk menjaga eksistensi dan kelestarian batik papua. Dengan perkembangan jaman di era digital saat ini, batik harus dapat berkembang sejalan dengan kemajuan teknologi yang ada tanpa mengurangi pemaknaan filosofis dari batik itu sendiri. Sebagai upaya untuk menjaga kelestarian batik papua penting untuk melakukan digitalisasi dalam pengembangan motif batik papua sehingga dapat mempercepat proses pembuatan yang dapat digunakan oleh para pengusaha batik. Selain itu dengan digitalisasi, motif batik papua dapat terinventarisasi dengan baik dan tidak menutup kemungkinan adanya peluasan fungsi dari motif batik papua nantinya. Salah satu media alternative yang dapat untuk digitalisasi pengembangan motif batik ini adalah pemanfaatan komputer grafis. Sebagai bagian dari produk artificial intelegence, komputer grafis tidak hanya sekedar platform yang dapat digunakan untuk programing, menghitung, menganalisis, menulis dan mendokumentasikan namun juga sebagai platform penunjang yang dapat digunakan untuk menggambar, merekonstruksi dan mendesain (Sunarya, n.d.). Sehingga pemanfaatan teknologi digital berbasis komputer grafis dapat menjadi inovasi desain dan efensiasi dalam mengeksplorasi keunggulan, keunikan serta gagasan untuk pengembangan motif batik, khususunya batik papua. Melalui penggunaan teknologi digital ini diharapkan dapat meningkatkan industry batik papua dan mampu beradaptasi dan berimprovisasi dengan keberadaan dan perkembangan batik modern yang berkembang saat ini.

\section{METODE PENELITIAN}

Untuk mengenali secara mendalam objek yang diteliti terkait dengan digitalisasi dalam pegembangan motif batik papua, maka dalam penelitian ini menggunakan jenis penelitian kualitatif untuk menjelaskan fenomena di masyarakat berdasarkan datadata yang dikumpulkan secara lengkap. Adapun teknik yang digunakan untuk mengumpulkan data-data pendukung dilakukan dengan wawancara, dan studi literatur. Wawancara dilakukan dengan Ibu Sri Berbudi yang merupakan salah satu pengusaha batik di Manokwari, Papua. Berdasarkan hasil wawancara, Ibu Sri sebagai pengrajin batik berharap batik papua dapat menampilkan dan memperkenalkan lebih ciri khas papua, karena batik papua saat ini belum memiliki banyak variasi motif terutama motif dengan objek fauna khas selain cendrawasih.

Data pendukung lainnya didapatkan dari berbagai literatur baik buku ataupun jurnal yang relevan dengan topik yang berkaitan dengan teori mengenai batik dan perancangan sejenis yang telah dilakukan sebelumnya sehingga dapat digunakan sebagai panduan untuk mentukan arah penelitian yang dilakukan untuk digitalisasi motif batik papua.

Untuk perancangan motif batik dalam penelitian ini menggunakan pendekatan teknik penciptaan seni. Dalam konteks metodologis, 
ada tiga tahap penciptaan seni diantaranya adalah eksplorasi, perancangan dan perwujudan (Gustami, 2007).

a. Eksplorasi :

Tahap awal dalam penelitian ini adalah eksplorasi yaitu langkah untuk penggalian permasalahan yang dikaji dan data-data verbal maupun visual yang didapatkan dari berbagai sumber. Adapun data ini dapat digunakan untuk mengidentifikasi ciri khas papua khususnya berkaitan dengan fauna khas papua yang dapat digunakan sebagai acuan dalam pengembangan motif batik papua. eksplorasi juga dilakukan berkaitan dengan software dalam komputer grafis yang akan digunakan untuk digitalisasi motif batik.

b. Perancangan

Perancangan dalam penelitian ini merupakan tahapan menuangkan gagasan dalam bentuk konsep yang telah diperoleh dari hasil analisis melalui penjaringan ide ke dalam visualisasi desain motif batik yang lakukan secara digital dengan software komputer grafis.

\section{c. Perwujudan karya}

Tahap perwujudan karya ini merupakan proses pengaplikasian hasil sketsa terseleksi ke dalam pembuatan desain yang berbentuk prototype desain digital motif batik papua dan mockup desain. Adapun dalam perwujudan karya ini desain dirancang secara digital berbasis komputer grafis. Hasil dari prototype desain nantinya dapat digunakan sebagai acuan bagi para pengrajin batik di papua.

\section{HASIL DAN PEMBAHASAN}

Papua merupakan wilayah yang mempunyai potensi wilayah berkembang dengan kekayaan sumber daya alam dan kebudaan yang dimilikinya. Karena terus berkembangnya kegiatan kepariwisataan di Papua maka keunikan budaya yang ada di Papua menjadi daya tarik bagi konsumen salah satunya batik Papua. Adanya batik papua dapat menjadi alternative souvenir yang menarik bagi wisatawan karena keunikannya. Dengan demikian Batik Papua mempunyai potensi sebagai industri kreatif yang dapat mendukung sektor pariwisata di daerah. Agar dapat memberikan variasi motif kepada wisatawan dalam memilih dan mengkoleksi motif batik papua perlu adanya inovasi dalam pengembangan motif batik dengan pemanfaatan komputer grafis. Melihat perkembangan batik modern saat ini, batik papua harus dapat berkembang sejalan dengan kemajuan teknologi agar dapat meningkatkan industri batik di papua. dengan inovasi tersebut tentunya dapat menarik minat wisatawan dan dapat memperluas pangsa pasar. Akan tetapi, dari data yang diperoleh motif batik papua selama ini hanya berorientasi pada motif burung Cendrawasih padahal motif tersebut sudah terkenal dan sudah cukup mewakilkan Papua. Selain cendrawasih masih banyak objek terutama fauna khas Papua yang dapat dijadikan motif batik diantaranya yaitu burung Kasuari dan Mambruk. Kedua jenis hewan tersebut merupakan burung endemik Papua dimana burung tersebut hanya hidup di pulau Papua dan sekitarnya.

\section{Kasuari Dan Mambruk Sebagai Icon Pada Motif Batik Papua}

Kasuari merupakan burung khas papua yang indah dengan bulu yang tebal dan tidak bersayap. Karena populasinya sangat sedikit di Indonesia maka burung kasuari termasuk dalam kategori satwa yang dilindungi. IUCN Redlist (International Union for the Consevation of Nature and Natural Resources) memasukkan burung kasuari gelambir ganda dalam status konservasi rentan (vulnerable) sejak tahun 1994. Namun status burung ini berubah menjadi berisiko rendah (least concern) pada tahun 2017. Hal tersebut tentunya menjadi ancaman bagi populasi burung kasuari dan menandakan bahwa hewan tersebut masih di incar oleh para pemburu. Adapun bagian dari burung tersebut yang menjadi incaran pemburu adalah yaitu daging, bulu dan telur.

Selain Kasuari, Mambruk juga termasuk satwa yang dilindungi oleh undangundang. Burung mambruk tergolong jenis merpati dan merupakan spesies paling besar diantara jenis merpati lain. Burung ini memiliki mahkota yang menarik dengan mata merah dikelilingi topeng hitam di sekitar mata dan bulu yang berwarna abu-abu serta maroon dibagian sayap. Di Indonesia mambruk memiliki tiga spesies diantaranya Goura cristata, Goura victoria, dan Goura 
scheepmakeri. Ketiga spesies mambruk tersebut dilindungi berdasarkan undangundang tetapi spesies yang paling terancam adalah mambruk polos atau Goura cristata.

King dan Nijboer (1994) dan Baptista dkk. (1997) melaporkan bahwa telah terjadi penangkapan secara besar - besaran terhadap satwa ini oleh para pedagang burung dan penduduk lokal. Tekanan perburuan yang terus menerus mengakibatkan ancaman terhadap kelestarian dan potensi ekonomi satwa ini. Penurunan populasi di alam disebabkan juga oleh perusakan habitat akibat penebangan hutan yang dilakukan oleh perusahaan - perusahaan kayu (Baptista, Trail, \& Horblit, 1997).

Adapun pemilihan hewan ini sebagai motif baru pada batik papua karena burung kasuari dan mambruk merupakan jenis spesies papua dan menjadi icon penting bagi papua. Langkah ini tentunya juga merupakan upaya untuk melestarikan dan mengenalkan bahwa hewan tersebut merupakan burung endemic papua yang dilindungi dan dapat digunakan sebgai daya tarik yang tersendiri bagi wisatawan melalui batik papua.

\section{Teknologi Digital dalam Motif Batik}

Saat ini kita berada di era teknologi, yang mana teknologi memiliki peran yang sangat penting dalam kehidupan sehari-hari. Pemanfaatan teknologi ini pun tentunya untuk memberikan efektifitas dan efisiensi dalam segala bidang, tidak terkecuali dalam industry batik. Dengan perkembangan jaman digital saat ini, batik harus dapat berkembang sejalan dengan kemajuan teknologi yang ada tanpa mengurangi pemaknaan filosofis dari batik itu sendiri. Untuk memperkenalkan dan melestarikan batik perlu usaha keras untuk bisa menampilkan identitas bangsa yang terkandung dalam filosof batik dengan teknologi yang ada. Oleh sebab itu sebagai upaya untuk menjaga kelestarian batik papua penting untuk melakukan digitalisasi dalam pengembangan motif batik papua sehingga dapat mempercepat proses pembuatan yang dapat digunakan oleh para pengusaha batik.
Dengan inovasi desain yang dilakukan akan memberikan efisiensi dalam proses produksi dan menghasilkan motif batik yang lebih variatif. Mengingat permasalahan yang sering dihadapi oleh pengrajin batik adalah stagnasi desain motif. Meskipun desain batik dibuat secara digital yang berbasis komputer grafis tidak akan menghilangkan makna dan filosofi dari batik itu sendiri dan tidak akan menghilangkan batik tradisional. Karena motif batik yang telah dihasilkan secara digital dapat dijadikan sebagai prototype yang dapat digunakan sebgai acuan dalam proses pengerjaan seperti batik tulis ataupun batik cap. Disamping itu, dengan adanya digitalisasi motif maka berbagai variasi desain motif yang telah dihasilkan akan terdokumentasikan dengan baik dan dapat dimanfaatkan jika nantinya ada perluasan fungsi dari batik itu sendiri.

\section{Inovasi Desain Batik Berbasis Komputer Grafis}

Kini batik berkembang secara modern dengan memanfaatkan teknologi yang mampu menghasilkan inovasi produk batik baru yang sesuai dengan selera global. Perkembangan ilmu pengetahuan dan teknologi saat ini, sangat berpengaruh terhadap percepatan tumbuhnya industri batik modern. Banyak inovasi yang unik dan kreatif yang dilakukan untuk memperkaya keanekaragaman batik khususnya batik papua, salah satunya adalah pemanfaatan media digital untuk penciptaan motif batik yang disesuaikan dengan ikon budaya dan trend yang berkembang saat ini.

$\begin{array}{clc}\text { Media } & \text { teknologi digital yang } \\ \text { mendukung } & \text { untuk }\end{array}$ keanekaragaman motif batik papua yaitu komputer grafis. Komputer grafis merupakan proses perancangan, penyimpanan dan manipulasi gambar baik 2 dimensi maupun 3 dimensi dengan menggunakan komputer. Ada banyak software dalam komputer grafis yang memiliki spesifikasi masing-masing dalam penggunaanya. Salah satunya adalah software berbasis vector yang dapat mempermudah proses pembuatan motif batik secara digital. Perpaduan garis lurus dan garis lengkung dalam objek motif batik yang disusun dengan konsep repetisi dapat divisualisasikan dengan 
mudah karena adanya teknologi dan komputer grafis yang berkembang saat ini. Sehingga dengan pemanfaatan teknologi dan komputer grafis dalam inovasi pengembangan motif batik secara digital tentunya akan meberikan kemudahan dan kecepatan dalam proses pembuatan motif bagi para pengrajin batik, khususnya batik papua.

\section{Proses Digitalisasi Motif Batik Papua}

Dalam proses perancangan motif batik berbasis digital sebagai upaya untuk menjaga eksistensi dan kelestarian batik papua ditengah perkembangan teknologi maka diperlukan beberapa tahap perancangan agar motif batik yang dihasilkan dapat memberikan variasi motif baru yang mewakili potensi wisata papua. Adapun tahap perancangan tersebut adalah sebagai berikut:

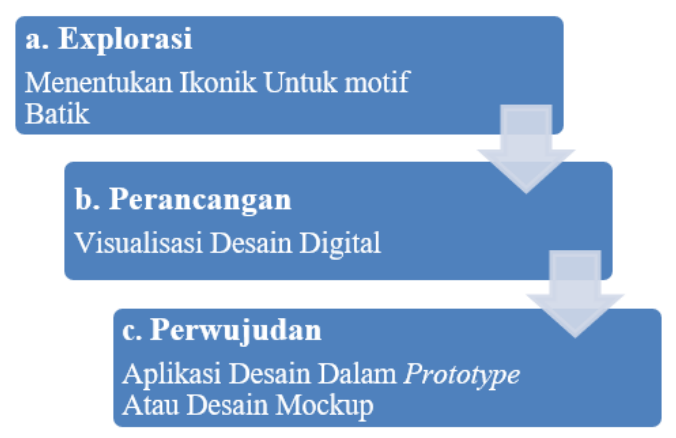

Gambar 1. Proses perancangan

(Sumber: Puri \& Alif, 2020)

\section{Eksplorasi}

$\begin{array}{rrrr}\text { Eksplorasi } & \text { yang dilakukan } & \text { dalam } \\ \text { langkah } \quad \text { awal } & \text { digitalisasi } & \text { untuk }\end{array}$
pengembangan motif batik ini yaitu dengan mengidentifikasi ikonik yang berkaitan dengan potensi wisata ataupun kebudayaan khas papua dan analisis kebutuhan alat atau software untuk merancang motif. Proses identifikasi dilakukan dengan anlisis perkembangan batik papua saat ini, karakteristik papua dan mengumpulkan data dari berbagai literature yang relevan dan dari nara sumber. Adapun ikonik yang didapatkan dari hasil identifikasi akan digunakan untuk pengembangan motif batik papua. Provinsi papua memiliki banyak sekali potensi yang mampu dijadikan ikonik dalam ragam hias batik papua. Namun dari berbagai keunggulan potensi yang dimiliki oleh papua tersebut. fauna khas papua lah yang diangkat sebagai ikonik untuk pengembangan motif batik papua berbasis digital dalam penelitian yang dilakukan. Mengingat selama ini batik papua dengan motif fauna hanya berorientasi pada motif burung cendrawasih. Padahal motif tersebut dirasa sudah cukup dikenal dan masih ada beberapa fauna khas papua yang dapat diangkat sebagai ragam hias batik. Faun khas tersebut adalah burung kasuari dan mambruk. Yang mana kasuari dan mambruk merupakan burung endemic papua yang dilindungi.

Selain itu juga dilakukan analisis terhadap ciri khas batik papua. analisis yang dilakukan yaitu untuk melihat ciri khas motif, objek dalam motif dan warna pada batik papua supaya motif yang dihasilkan nantinya tetap sesuai dengan ciri khas dari batik papua selama ini. Mengingat bahwa batik di setiap daerah memiliki ciri khas yang berbeda seperti batik pedalaman yang biasanya memiliki ciri khas warna yang gelap dan bati pesisir yang biasanya memiliki warna yang cerah. Menurut (Marthen \& Mambraku, 2014), Batik papua memiliki ciri khas dalam motif, objek motif dan warna. Adapun motif batik papua biasanya mempunya pola geometris dengan ornament yang tersusun sistematis dan non geometris dengan susunan tidak teratur. Objek motif dalam batik papua biasanya menggambarkan objek yang ada didaerah papua yaitu seperti flora, fauna, rumah adat dan sebagainya. Sedangkan Warna pada batik papua biasanya cenderung menggunakan warna motif gelap dengan kombinasi background yang cerah dan beberapa warna terang dan gold pada ragam hias.
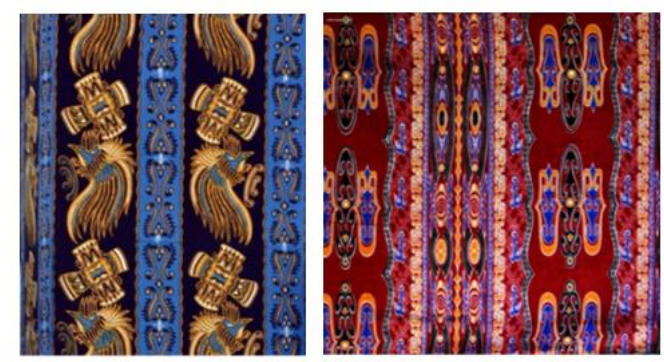

Gambar 2. Batik papua

(Sumber: Victor Marthen Iriano Mambraku) 
Dalam tahap eksplorasi ini juga dilaukan analisis kebutuhan alat yang akan digunakan. Adapun output dalam penelitian ini adalah prototype desain motif batik dan mockup, maka dalam proses perancangannya akan menggunakan software dalam komputer grafis. Ada banyak software dalam komputer grafis yang memiliki spesifikasi masingmasing dalam penggunaanya. Untuk merancang digitalisasi motif batik papua akan digunakan software berbasis vector yaitu adobe illustrator. Adobe illustrator merupakan software yang dikembangkan oleh Adobe yang memiliki spesifikasi sebagai pengolah grafis berbasis vector. Adapun pemilihan adobe illustrator karena dalam prosesnya banyak melakukan pengolahan gambar motif batik dalam bentuk garis dan kurva. Motif batik yang dihasilkan berupa kombinasi garis lurus dan garis lengkung.

\section{Perancangan}

Visualisasi yang dilakukan dalam pengembangan batik papua berbasis digital diawali dengan implementasi ide atau konsep yang telah diperoleh dari tahap eksplorasi ke dalam sektsa untuk kemudian divisualisasikan secara digital. Dalam proses visualisasi dibutuhkan beberapa studi visual berkaitan dengan object yang akan dijadikan acuan dalam proses desain. Tahap awal visualisasi adalah pembuatan sketsa dengan menyederhanakan object yang diadaptasi dengan stilasi. Gaya stilasi atau stiliran dalam ornamen adalah menggubah bentuk hingga menjadi luwes, umumnya menggunakan garis-garis lengkung hasil gubahan dari kehidupan yang ada pada alam ditransfer diatas kertas sebagai manifestasi ideal yang di ekspresikan dengan media titik, garis, bidang, warna, dan tekstur dalam bentuk stiliran (Azizah, 2015). Pembuatan sketsa dilakukan dengan mengambil bentuk asli dari object studi visual yaitu burung kasuari dan mambruk untuk disederhanakan namun tanpa mengubah bentuk dasar dari object tersebut. Tujuan dilakukan stilasi ini adalah mengurangi bagian-bagian yang kompleks dari objek asli burung kasuari dan mambruk untuk disederhanakan menjadi bentuk baru dengan gaya stilasi atau dekorasi yang identik dengan batik namun tanpa menghilangkan karakter asli dari object yang diadaptasi. Hasil sketsa kemudian discan untuk dijadikan file agar dapat disimpan di komputer karena proses desain akan dilakukan dengan perangkat komputer. Semua file yang dilakukan scanning disimpan menjadi image untuk dilakukan digitalisasi. Teknik dalam proses digitalisasi dilakukan dengan menggunakan software adobe Illustrator. Adobe illustrator merupakan software pengolah grafis yang mudah di gunakan dan mengakses beragam fitur yang ada, terutama dengan sistem pengelompokan fasilitas melalui menu, toolbox, palete dan sebagainya (Suhendi \& Rizki, 2009). Sebagai salah satu software berbasis vector dalam komputer grafis, adobe illustrator merupakan software pengolah grafis yang mudah digunakan dan kompatibel dengan perangkat lunak yang lain. Berikut adalah hasil penyederhanaan dari burung kasuari dan mambruk yang dilakukan dengan software adobe illustrator:

Table 1: Penyederhanaan burung kasuari menjadi motif batik

[sumber: Puri, Dimas \& Alif, 2020]

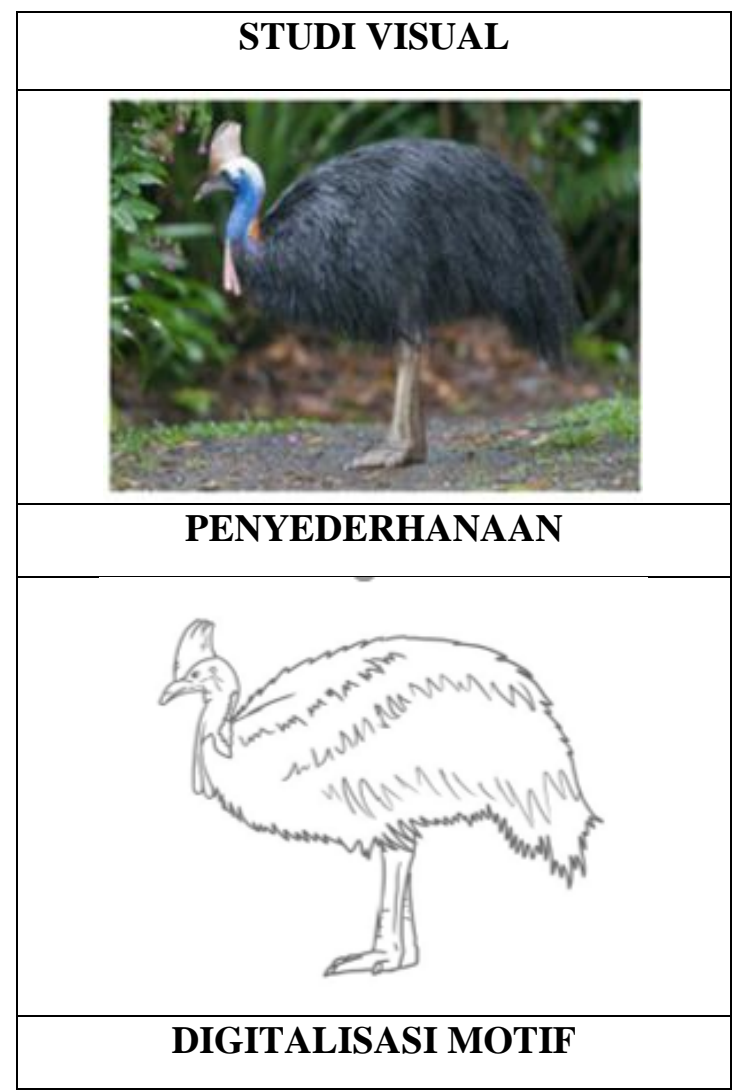




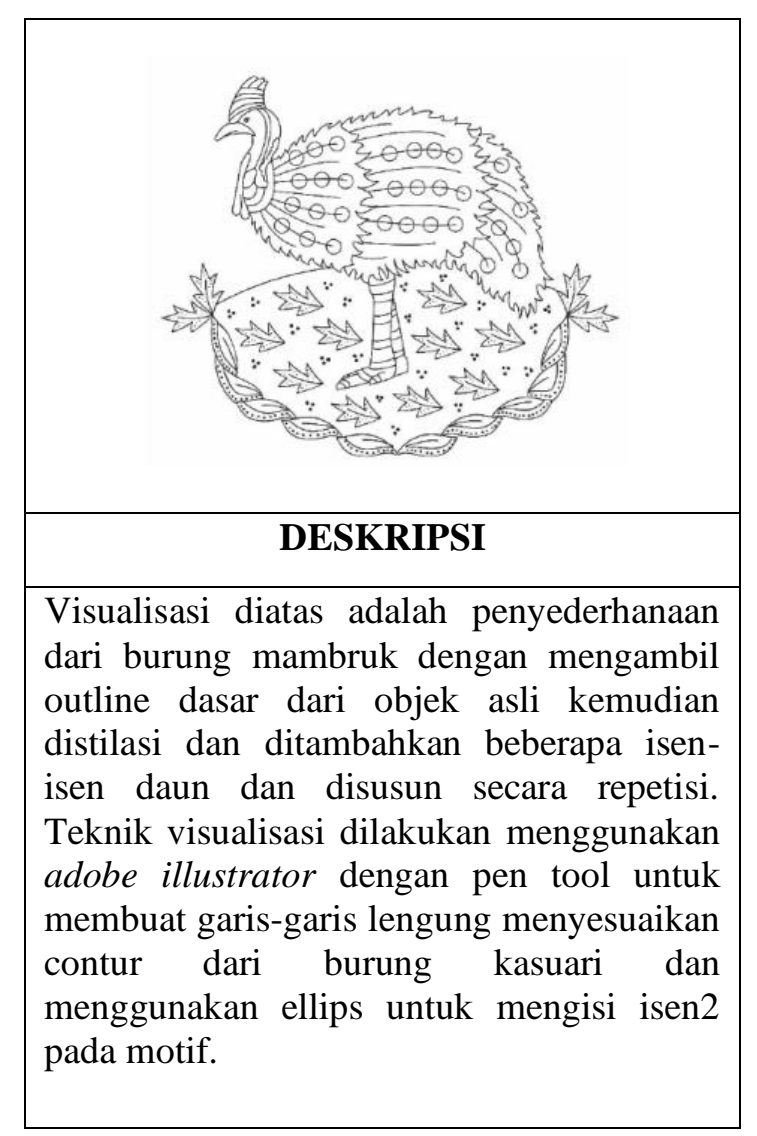

Table 2: Penyederhanaan burung mambruk menjadi motif batik

(sumber: Puri, Dimas \& Alif, 2020)

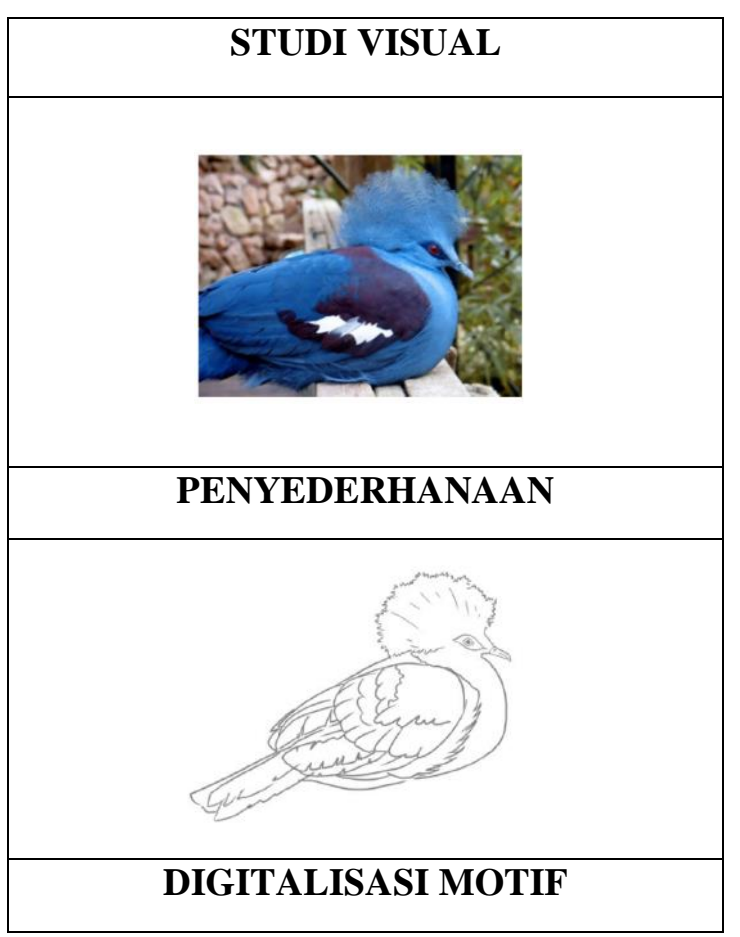

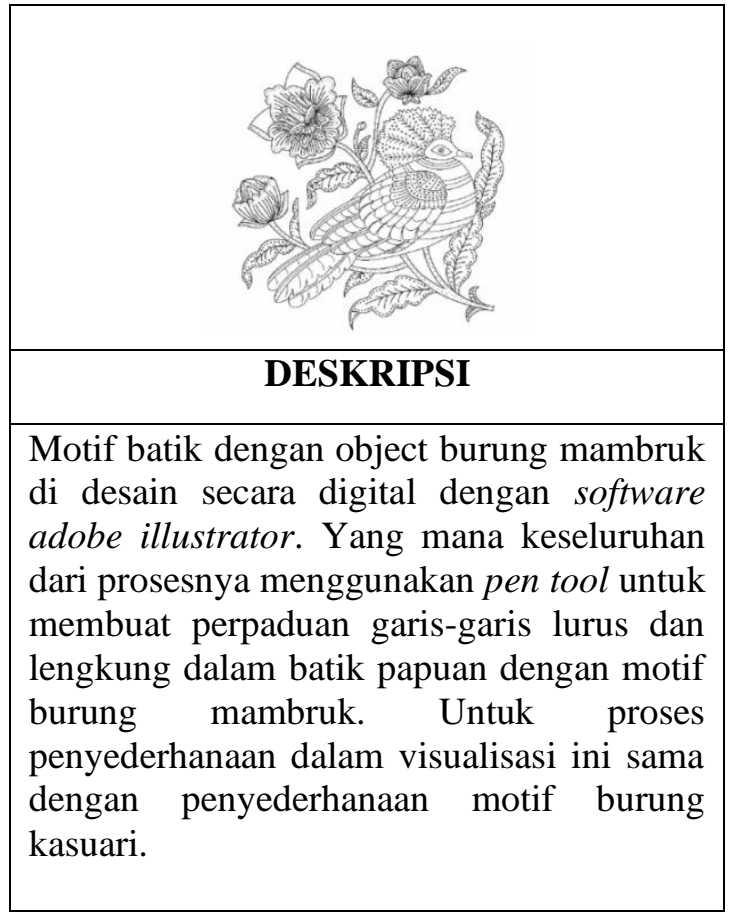

Penyederhanaan object dilakukan dengan tracing dari sketsa manual menjadi digital berupa outline menggunakan kolaborasi pentool dan direct selection untuk membuat garis-garis vector pada adobe illustrator. Dengan proses yang sama object burung yang telah disederhanakan kemudian diisi dengan ornament yang bergaya stilasi. Banyaknya fitur yang disedikan pada adobe illustrator sangat membantu dalam proses penyederhanaan object dan mampu menghasilkan penyederhanaan burung kasuari dan mmabruk dengan garis-garis yang halus dan tegas dalam berbagai tampilan. dengan pemanfaatan fitur rule pada adobe illustrator memudahkan pembuatan komposisi motif geometris dan non geometris secara presisi.

Penggunaan fitur-fitur dalam adobe illustrator menjadikan karakteristik dari motif batik papua yang dirancang dapat tervisualisasikan dengan mudah dan sesuai dengan konsep. Proses selanjutnya adalah pewarnaan pada motif utama, motif pendukung dan background. Tool yang digunakan pada tahap coloring adalah color pallete untuk pemilihan warna-warna yang akan diaplikasikan pada motif batik. Pemilihan warna disesuaikan dengan ciri khas warna pada batik papua yang cenderung menggunakan warna cerah pada motif dan 
gelap pada background. warna pada motif utama menggunakan perpaduan warna orange tua sampai kuning dan warna ungu pada background dengan outline putih. Lalu pada motif pendukung warna yang digunakan adalah kuning kehijauan. berikut adalah proses pewarnaan pada adobe illustrator:
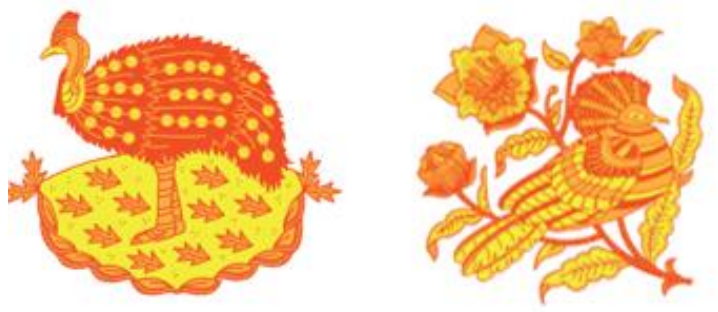

Gambar 3. Pengaplikasian warna pada motif utama

(sumber: Puri, Dimas \& Alif, 2020)

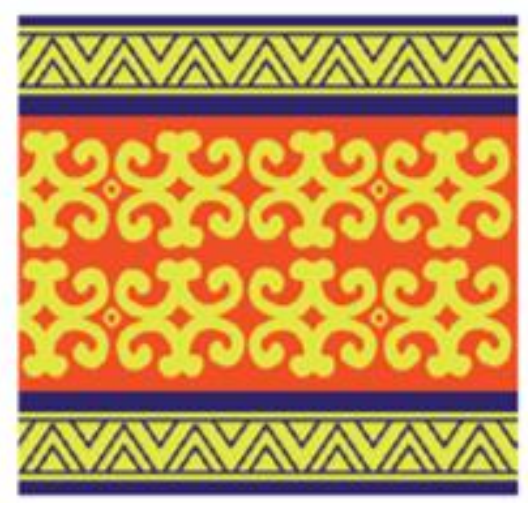

Gambar 4. Pengaplikasian warna pada motif pinggiran

(sumber: Puri, Dimas \& Alif, 2020)

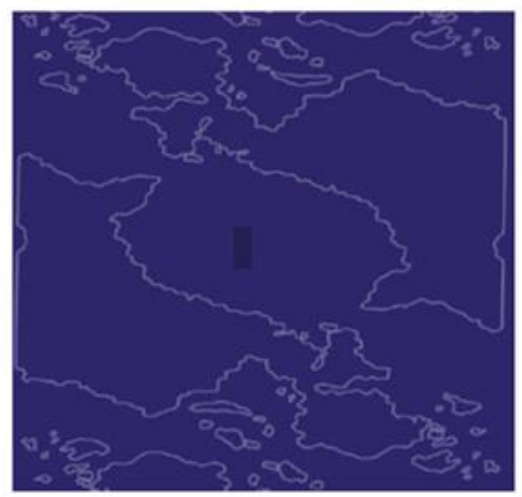

Gambar 5. Pengaplikasian warna pada background motif

(sumber: Puri, Dimas \& Alif, 2020)

\section{Perwujudan}

Langkah perwujudan dalam proses perancangan ini adalah implementasi hasil desain yang diolah dengan adobe illustrator untuk dijadikan mockup atau prototype. Media yang dijadikan untuk mockup didesain dengan menggunakan software yang sama untuk mendesain motif yaitu adobe illustrator. Adobe Illustrator sebagai software pengolah grafis sangat menunjang proses pembuatan motif batik ini. Hal ini berkaitan dengan pembuatan garis yang lurus, garis lengkung, simetris dan presisi ukuran objek yang dibuat. Selain itu fasilitas adobe illustrator sangat mempermudah dalam menduplicate motif batik secara otomatis dan dengan ukuran dan penempatan yang presisi karena ciri utama batik adalah penyusunan motif yang berulang atau repetisi.

Pengembangan motif batik dalam penelitian ini sampai sebatas pembuatan prototype, karena prototype merupakan tahapan yang sangat penting dan menjadi tahap dasar dalam pembuatan batik papua. dalam pembuatan prototype dilakukan peyususnan bererapa motif yang telah di visualisasikan dan dikombinasikan dengan beberapa ragam hias dan isen-isen. Kombinasi motif, ragam hias dan isen-isen disusun secara berulang sesuai dengan konsep batik. Berikut adalah prototype yang dihasilkan

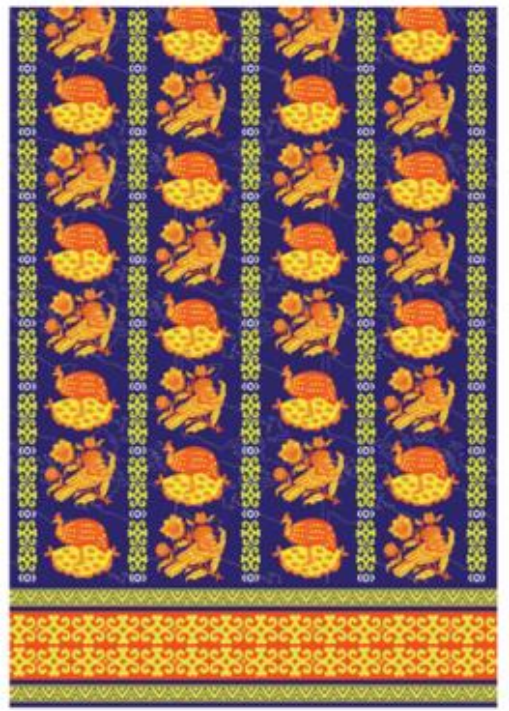

Gambar 6. Prototype motif batik papua (sumber: Puri \& Alif, 2020] 
Prototype yang telah dibuat dapat diaplikasikan kedalam pembuatan batik modern dengan teknik printer, namun tidak menutup kemungkinan prototype yang dibuat secara digital mengguankan komputer nantinya diguankan sebagai acuan dalam pembuatan batik secara tradisonal. Adapaun prototype yang dihasilkan menampilkan bentuk dan warna yang sama dengan motif yang akan diimplementasikan pada kain batik dan beberapa media lainnya. Berikut adalah implementasi motif batik papua yang diapliaksikan dalam mockup media kain.

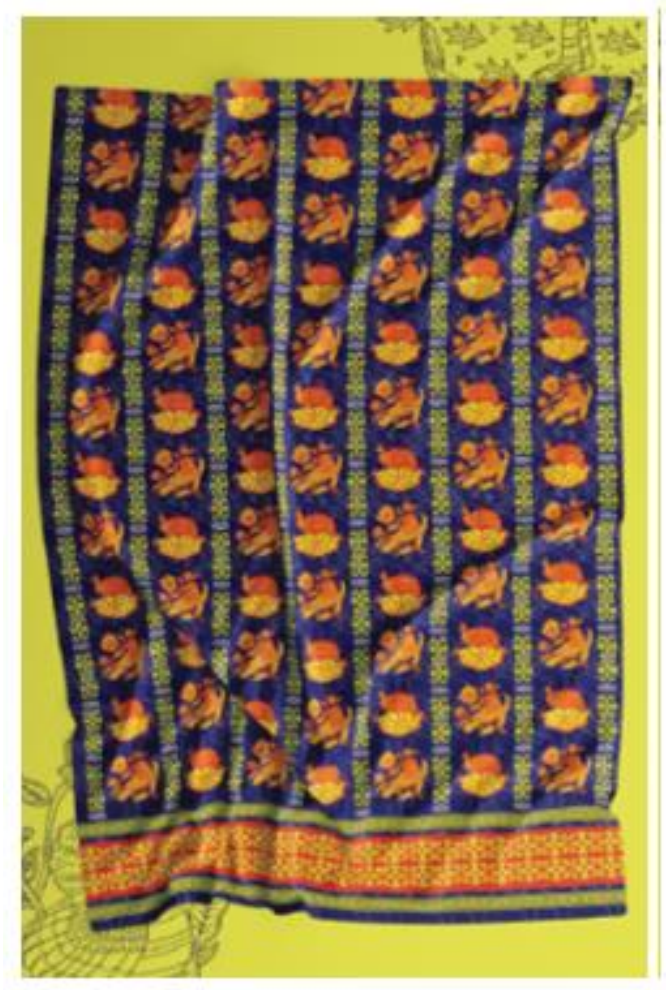

Gambar 7. Mockup motif batik papua pada kain

(sumber: Puri, Dimas \& Alif, 2020)

\section{KESIMPULAN}

Dari hasil penelitian yang telah dilakukan maka dapat ditarik kesimpulan bahwa hadirnya digitalisasi motif batik berbasis komputer grafis menjadi peluang bagi perkembangan batik papua. Dengan adanya teknologi komputer, proses pembuatan motif batik dapat dilakuakn lebih cepat. Fasilitas tool pada adobe illustrator sebagai software komputer grafis berbasis vector

sangat menunjang dalam proses pembuatan motif dengan garis yang lurus ataupun lengkung, ukuran yang presisi dan penempatan yang simetris dalam menyusun motif batik secara repetisi. Sehingga dengan implementasi komputer grafis dalam pengembangan motif batik dapat memberikan kemudahan bagi para pengrajin batik dan dapat menjadikan batik papua sebagai sebagai industri kreatif yang dapat mendukung sektor pariwisata daerah di papua.

\section{DAFTAR PUSTAKA}

Azizah, Z. D. (2015). Deformasi Flora dan fauna dalam Motif Batik pada Pembelajaran Seni Budaya Kelas VIIIC SMPN 1 Turi. Skripsi, Yogyakarta: Universitas Negeri Yogyakarta.

Baptista, L. F., Trail, P. W., \& Horblit, H. M. (1997). Family Columbidae (pigeons and doves). Handbook of the Birds of the World, 4, 60-243.

Gustami, S. P. (2007). Butir-butir mutiara estetika timur: ide dasar penciptaan seni kriya Indonesia. Prasista.

Marthen, V., \& Mambraku, I. (2014). MOTIF RAGAM HIAS BATIK PADA RUANG PUBLIK.

Salsabila, F. (2019). Perancangan Pengembangan Batik Sentani Papua. Universitas Kristen Maranatha.

Suhendi, E., \& Rizki, G. (2009). Membuat Desain Profesional Dengan Adobe Illustrator. Bandung: Informatika.

Sunarya, Y. Y. (n.d.). Pengembangan fungsi dan desain batik dengan pendekatan 'Smart Batik'menghadapi perkembangan teknologi dan tren selera pasar global. 